\title{
Karakter Indeks Pengembangan Gelatin Taut Silang dengan Sukrosa Teroksidasi dan Glutaraldehid
}

\section{Swelling Index Character of Gelatin Cross-Linked with Oxidized Sucrose and Glutaraldehyde}

\author{
Nursalam Hamzah*1 ${ }^{1}$ Nurmi $^{2}$, Mukhriani $^{1}$, Asrul Ismail ${ }^{1}$ \\ ${ }^{1}$ Jurusan Farmasi Fakultas Kedokteran dan Ilmu Kesehatan Universitas Islam Negeri Alauddin, \\ Jalan H.M. Yasin Limpo No. 36, Sungguminasa Kabupaten Gowa Sulawesi Selatan \\ ${ }^{2}$ Mahasiswa Prodi Farmasi Fakultas Kedokteran dan Ilmu Kesehatan Universitas Islam Negeri Alauddin, \\ Jalan H.M. Yasin Limpo No. 36, Sungguminasa Kabupaten Gowa Sulawesi Selatan
}

Email: nursalam.hamzah@uin-alauddin.ac.id

\begin{abstract}
ABSTRAK
Ikan merupakan salah satu sumber alternatif gelatin halal tetapi memiliki kualitas yang lebih rendah jika dibandingkan dengan gelatin babi. Taut silang dapat menjadi salah satu solusi untuk meningkatkan kualitasnya. Tujuan penelitian adalah mempelajari pengaruh bahan penaut silang terhadap karakter indeks pengembangan. Prosedur dimulai dengan ekstraksi gelatin dari sisik ikan bandeng dengan metode perendaman basa dan asam. Pembuatan gelatin taut silang dengan cara mencampurkan larutan gelatin ikan bandeng 5\% sebanyak $50 \mathrm{ml}$ dengan bahan penaut silang dengan konsentrasi bervariasi sebanyak $50 \mathrm{ml}$. Campuran kemudian diaduk hingga merata dan dikeringkan dalam oven pada suhu $70^{\circ} \mathrm{C}$. Penelitian ini menggunakan bahan penaut silang, yaitu sukrosa teroksidasi dan glutaraldehid. Hasil gelatin taut silang diuji karakteristik indeks pengembangannya. Selain itu, juga digunakan sampel gelatin ikan komersial sebagai pembanding. Pembentukan taut silang ditandai dengan perubahan konsistensi sampel dari larutan menjadi gel. Perubahan konsistensi paling signifikan terlihat pada gelatin taut silang dengan sukrosa teroksidasi dan glutaraldehid. Dari penelitian ini dapat disimpulkan bahwa peningkatan kadar bahan penaut silang menurunkan indeks pengembangan.
\end{abstract}

Kata Kunci : Gelatin, taut silang, swelling index.

\begin{abstract}
Fish is an alternative source of halal gelatin but has a weak quality compared to porcine gelatin. Cross links can be solution to improve its quality. The purpose of this study was to study the effect of cross-linking agents on the swelling index character. The procedure begins with gelatin extraction from milkfish scales by the alkaline and acid soaking method. The making of cross-linking gelatin by mixing $50 \mathrm{ml}$ milkfish gelatin solution $5 \%$ with $50 \mathrm{ml}$ crosslinking agents with varying concentrations. The mixture is then stirred until homogenous and dried in oven at $70^{\circ} \mathrm{C}$. This research uses cross-linking agents, namely oxidized sucrose and glutaraldehyde. The cross-linked gelatin products were tested for swelling index characteristics. In addition, commercial fish gelatin samples were also used as standard. The formation of cross-links is characterized by the changes in the consistency of the sample from solution to gel. The most significant change in consistency was seen in crosslinked gelatin with oxidized sucrose and glutaraldehyde. From this study, it can be concluded that increasing levels of cross-linking agents decreases the swelling index.
\end{abstract}

Keywords: Gelatin, cross-linking, swelling index

\section{PENDAHULUAN}

Gelatin merupakan jenis derivat protein dari serat kolagen yang umumnya dapat diekstraksi dari tulang dan kulit, digunakan paling besar dalam bidang makanan dan farmasi. Sumber terbesar produksi gelatin di dunia dari bahan baku kulit babi yaitu sekitar 45,8; kulit sekitar 28,4\% dan tulang sapi 
sekitar 24,3\% (Darwin, Ridhay, \& Hardi, 2018). Gelatin digunakan dalam industri makanan sebagai bahan pembuatan kue dan susu. Dalam kesehatan dan farmasi, gelatin digunakan sebagai matriks untuk implan atau plester, mikrosfer pemberian obat injeksi, dan intravena, pembuatan cangkang kapsul keras dan lunak. Gelatin juga digunakan untuk mengurangi kadar karbohidrat dalam makanan yang diformulasikan untuk pasien diabetes (Karim \& Bhat, 2009).

Indonesia merupakan negara pengguna gelatin dalam jumlah yang besar, tetapi memiliki beberapa keterbatasan dalam penggunaannya, sehingga membutuhkan sumber alternatif. Menurut data BPS tahun 2007 Indonesia mengimpor gelatin sekitar 3.304 ton, dan angka ini diperkirakan akan semakin meningkat seiring meningkatnya penduduk dan kebutuhan akan gelatin (Rapika, Dzulfikar, \& Zumarni, 2016). Penggunaan gelatin menjadi permasalahan adalah warga Indonesia yang terdiri dari beranekaragam agama. Bagi pemeluk Agama Islam, gelatin yang berasal dari bahan baku babi haram untuk dikonsumsi, sedangkan gelatin yang berasal dari sapi tidak dikonsumsi pemeluk Agama Hindu karena sapi dianggap sebagai hewan suci (Darwin, Ridhay, \& Hardi, 2018). Gelatin yang bersumber dari sapi juga menimbulkan masalah kesehatan. Marak wabah sapi Bovine spongiform encephalopathy (BSE) atau dikenal dengan penyakit sapi gila yang telah mengakibatkan adanya pembatasan penggunaan gelatin sapi dalam produk makanan (Karim \& Bhat, 2009). Beberapa tahun terakhir ini, ikan dan unggas telah mendapatkan perhatian yang besar untuk dijadikan bahan dasar produksi gelatin alternatif. Tulang ikan mengandung sekitar $18,6 \%$ kolagen dari 19,86\% unsur organik protein kompleks yang menjadi bahan pembuatan gelatin (Darwin, Ridhay, \& Hardi, 2018).

Walaupun merupakan bahan yang halal, gelatin yang bersumber dari ikan memiliki kekurangan, sehingga perlu modifikasi untuk meningkatkan kualitasnya. Ikan dapat langsung digunakan tanpa pengawasan penyembelihan, seperti pada hewan mamalia atau unggas. Gelatin ikan memiliki sifat termal dan mekanik yang rendah (Karim \& Bhat, 2009). Penggunaan gelatin ini biasanya terbatas pada suhu yang lebih tinggi (diatas $35^{\circ} \mathrm{C}$ ). Struktur ikatan sekunder pecah akibat kenaikan suhu mengakibatkan hancurnya karakteristik fisik. Aplikasi yang lebih lanjut gelatin relatif murah perlu modifikasi sehingga memperbaiki kualitasnya. Taut silang kimia antar rantai protein gelatin dapat digunakan untuk menstabilkan sifat mekanik gel dari gelatin (Rajalaxmi, Marcus, \& Arthur, 2013). Pilihan dan desain reagen taut silang tergantung pada aplikasi spesifik. Pada masing-masing spesies molekuler untuk taut silang memiliki spesifikasi yang berbeda. Pada protein dapat terjadi reaksi spesifikasi terhadap gugus tertentu, misalnya amino, sulfhidril, carboryl guanidinyl, imidazol, dan 
rantai samping asam amino lainnya (Wong \& Jameson, 2011).

Beberapa agen pentaut silang yang dapat digunakan untuk mentaut silang rantai gelatin secara kimia. Taut silang dapat meningkatkan stabilitas gel dan ketahanan terhadap degradasi termal serta meningkatkan sifat mekanik gelatin. Bahan penaut silang termasuk karbodiimida, formaldehid, glutaraldehid, polisakarida teroksidasi seperti dextran, kondroitin sulfat, dan pati, golongan fenolik (asam galat) dan asam sitrat dapat mempengaruhi sifat gel gelatin, karena efek pelembab sehingga meningkatkan stabilitas gel (Rajalaxmi, Marcus, \& Arthur, 2013; Santos, Esquerdo, Moura, \& Pinto, 2018). Bahan yang paling umum digunakan untuk taut silang adalah sukrosa teroksidasi dan glutaraldehid. Penelitian pembuatan dan pengujian indeks pengembangan gelatin taut silang dapat dilakukan dengan maksud agar memperoleh gelatin dengan karekteristik tinggi yang halal.

\section{METODE PENELITIAN}

\section{Ekstraksi gelatin}

Sisik diperoleh dari Industri pada Kawasan Industri Makassar (KIMA). Sisik ikan bandeng dibersihkan dengan cara membuang kotoran, lemak dan sisa daging dari sisik, kemudian sampel dikeringkan di lemari pengering. Sisik ikan bandeng sebanyak 100 gram direndam dengan larutan $\mathrm{NaOH} 1 \mathrm{~N}$ sebanyak $700 \mathrm{~mL}$ pada suhu $30^{\circ} \mathrm{C}$ selama 1 jam. Kemudian dicuci dengan menggunakan
$1 \mathrm{~L}$ air suling hingga $\mathrm{pH}$ netral, diulangi tiga kali. Selanjutnya ampas direndam lagi dengan larutan $\mathrm{HCl} 1 \mathrm{~N}$ sebanyak $700 \mathrm{~mL}$ pada suhu $30^{\circ} \mathrm{C}$ selama 1 jam. Kemudian dicuci lagi dengan menggunakan air suling hingga $\mathrm{pH}$ netral, diulangi tiga kali. Ampas kembali direndam dengan air suling sebanyak $700 \mathrm{~mL}$, dipanaskan di atas waterbath suhu $90^{\circ} \mathrm{C}$ selama 8 jam. Kemudian disaring. Filtrat dikeringkan dalam oven pada suhu $70^{\circ} \mathrm{C}$ selama 48-72 jam. Setelah kering kemudian gelatin hasil ekstraksi dihaluskan.

\section{Pembuatan gelatin taut silang}

Taut Silang dengan sukrosa teroksidasi

Sampel yang digunakan adalah gelatin sisik ikan bandeng dan gelatin komersil (Modernist Pantry). Prosedur pembuatan menggunakan prosedur yang digunakan oleh Jalaja \& James (2015) dengan sedikit perubahan. Larutan sukrosa oksidasi dibuat dengan mencampur sukrosa dan $\mathrm{NaIO}_{4}(1: 2$ dalam mol, komposisi sebagaimana tersaji dalam tabel 1) dalam air $50 \mathrm{~mL}$. Campuran direaksikan dalam ruangan gelap selama 6 jam. Larutan gelatin dibuat dengan melarutkan gelatin $5 \mathrm{~g}$ dalam $50 \mathrm{ml}$ aquades. Kedua larutan dicampurkan kemudian didiamkan selama 36 jam, terakhir dikeringkan di oven pada suhu $70^{\circ} \mathrm{C}$.

\section{Taut Silang dengan glutaraldehid}

Sampel yang digunakan adalah gelatin sisik ikan bandeng dan gelatin komersil. Pembuatan gelatin modifikasi dengan glutaraldehid dilakukan dengan membuat 
Tabel 1. Komposisi sukrosa, $\mathrm{NaIO}_{4}$ dan gelatin dalam $100 \mathrm{~mL}$ campuran akhir dalam air

\begin{tabular}{cccc}
\hline Konsentrasi & $\begin{array}{c}\text { Sukrosa } \\
\mathrm{mg}\end{array}$ & $\begin{array}{c}\mathrm{NaIO}_{4} \\
\mathrm{mg}\end{array}$ & $\begin{array}{c}\text { Gelatin } \\
\mathrm{mg}\end{array}$ \\
\hline Sukrosa 0,1\% & 100 & 127 & 5000 \\
Sukrosa 0,25\% & 250 & 310 & 5000 \\
Sukrosa 0,5\% & 500 & 639 & 5000 \\
\hline
\end{tabular}

Keterangan : Gelatin yang digunakan adalah gelatin ikan bandeng atau ikan komersil

Tabel 2. Komposisi glutaraldehid dan gelatin dalam $100 \mathrm{~mL}$ campuran akhir dalam air

\begin{tabular}{llc}
\hline Konsentrasi & $\begin{array}{l}\text { Glutaraldehid } \\
25 \% \\
\mathrm{~mL}\end{array}$ & $\begin{array}{l}\text { Gelatin } \\
\mathrm{mg}\end{array}$ \\
\hline $\begin{array}{l}\text { Glutaraldehid } 0,1 \% \\
\text { Glutaraldehid 0,05\% }\end{array}$ & 0,4 & 5000 \\
Glutaraldehid 0,025\% & $0,1 \mathrm{~mL}$ & 5000 \\
\hline $\begin{array}{l}\text { Keterangan : Gelatin yang digunakan } \\
\text { gelatin ikan bandeng atau ikan komersil }\end{array}$ & adalah \\
\hline
\end{tabular}

larutan glutaraldehid dengan cara mengambil 0,4 mL; 0,2 mL; dan 0,1 mL glutaraldehid $25 \%$ dan dicukupkan hingga $50 \mathrm{ml}$ dengan penambahan aquades. Larutan gelatin dibuat dengan melarutkan $5 \mathrm{~g}$ serbuk gelatin dalam $50 \mathrm{ml}$ aquades dengan bantuan pemanasan. Kedua larutan dicampurkan dan didiamkan selama 36 jam. Kemudian campuran dikeringkan dalam oven pada suhu $70^{\circ} \mathrm{C}$ hingga kering. Terakhir, gelatin hasil modifikasi dihaluskan. Komposisi lihat pada tabel 2.

\section{Pengujian Indeks Pengembangan}

Pengujian indeks pengembangan dilakukan terhadap sampel yaitu gelatin bandeng, gelatin komersil, gelatin bandeng modifikasi, gelatin komersil modifikasi, dan gelatin sapi standar (Sigma). Sampel ditimbang sebanyak 2 gram, selanjutnya gelatin yang telah ditimbang dimasukkan dalam gelas ukur kemudian di larutkan dengan $50 \mathrm{ml}$ aquades. Sampel didiamkan selama 12 jam. Volume diamati pada saat awal sebelum dan setelah perendaman.

$$
I P=\frac{V-V 0}{V 0} X 100 \%
$$

Dimana IP $=$ indeks pengembangan, $\mathrm{V}=$ volume setelah perendaman, dan $\mathrm{V} 0=$ volume awal sebelum perendaman.

\section{HASIL DAN PEMBAHASAN}

Gelatin adalah contoh bahan yang dihasilkan dari alam yang terdiri dari protein sekitar 85\% hingga 92\%, sisanya adalah bahan mineral dan kelembaban yang masih tersisa setelah pengeringan (Reinhard Schrieber, 2007). Gelatin ikan bandeng yang digunakan diperoleh dari ekstraksi gelatin sisik ikan bandeng meliputi preparasi sampel, pra-ekstraksi, ekstraksi dan pengeringan. Proses pra-ekstraksi dengan perendaman basa dan asam berfungsi untuk menghilangkan kalsium dan garam-garam mineral (senyawa lain selain kolagen) yang terkandung dalam sampel sisik ikan, sehingga sampel menjadi lunak atau osein yang terdapat kolagen didalamnya. Selain itu, larutan $\mathrm{pH}$ basa dan asam diharapkan melarutkan senyawa non kolagen, serta dapat merubah serat kolagen triple heliks menjadi rantai tunggal. Gelatin mudah larut dalam air, sehingga cairan pelarut yang digunakan adalah air dengan bantuan pemanasan.

Pembuatan gelatin modifikasi dilakukan dengan melakukan taut silang gelatin dengan 
Tabel 3. Indeks pengembangan

\begin{tabular}{|l|c|c|c|c|c}
\hline Kelompok & Sampel & Konsentrasi & $\begin{array}{c}\text { Volume } \\
\text { Awal } \\
\mathrm{mL}\end{array}$ & $\begin{array}{c}\text { Volume } \\
\text { Akhir } \\
\mathrm{mL}\end{array}$ & $\begin{array}{c}\text { Indeks } \\
\text { Pengembangan } \\
\%\end{array}$ \\
\hline BaKo & Bandeng & - & 4 & 5,5 & 37,5 \\
\hline IKKo & Ikan Komersil & - & 3,5 & 8 & 128,6 \\
\hline SaKo & Sapi & - & 3 & 15 & 400 \\
\hline BaSu 0,1 & Bandeng & Sukrosa 0,1\% & 5 & 24 & 380 \\
\hline BaSu 0,25 & Bandeng & Sukrosa 0,25\% & 4 & 19 & 375 \\
\hline BaSu 0,5 & Bandeng & Sukrosa 0,5\% & 4 & 15 & 275 \\
\hline IKSu 0,1 & Ikan Komersil & Sukrosa 0,1\% & 5 & 22 & 340 \\
\hline IKSu 0,25 & Ikan Komersil & Sukrosa 0,25\% & 4 & 16 & 300 \\
\hline IKSu 0,5 & Ikan Komersil & Sukrosa 0,5\% & 5 & 16 & 220 \\
\hline BaGu 0,025 & Bandeng & Glutaraldehid 0,025\% & 3,5 & 10 & 185,7 \\
\hline BaGu 0,05 & Bandeng & Glutaraldehid 0,05\% & 5 & 9 & 80 \\
\hline BaGu 0,1 & Bandeng & Glutaraldehid 0,1\% & 5 & 7 & 40 \\
\hline IKGu 0,025 & Ikan Komersil & Glutaraldehid 0,025\% & 5 & 20 & 300 \\
\hline IKGu 0,05 & Ikan Komersil & Glutaraldehid 0,05\% & 5 & 26 & 420 \\
\hline IKGu 0,1 & Ikan Komersil & Glutaraldehid 0,1\% & 5 & 6 & 20 \\
\hline
\end{tabular}

bahan pentaut silang yakni, sukrosa teroksidasi dan glutaraldehid. Sukrosa teroksidasi dibentuk dengan mengoksidasi natrium periodat membentuk sukrosa aldehid (Jalaja \& James, 2015). Gugus aldehid pada sukrosa teroksidasi dan glutaraldehid akan berikatan dengan gugus amin bebas pada lisin membentuk gugus imida $(-\mathrm{C}=\mathrm{N}-)$. Satu molekul sukrosa aldehid dapat mengikat maksimal empat gugus amin, sedangkan glutaraldehid dapat mengikat dua gugus amin, sesuai dengan jumlah gugus aldehid pada

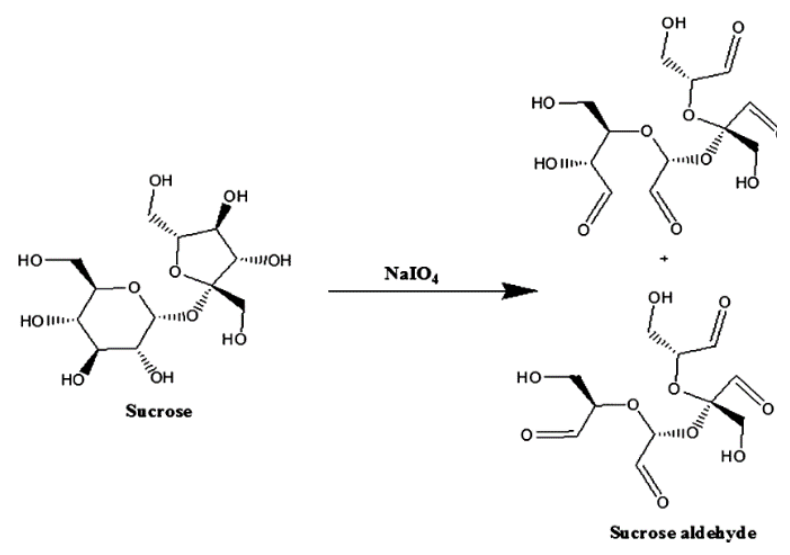

Gambar 1. Reaksi oksidasi sukrosa (Jalaja \& James, 2015) molekul. Setelah dilakukan proses modifikasi gelatin dengan metode taut silang maka tahapan selanjutnya adalah dilakukan pengujian berupa pengujian indeks pengembangan.

Gelatin dapat ditaut silang dengan sukrosa teroksidasi dan glutaraldehid. Setelah penambahan bahan penaut silang, konsistensi gelatin mengalami perubahan konsistensi dari larutan menjadi gel. Semakin besar konsentrasi bahan penaut silang, semakin kental gel yang terbentuk, bahkan membentuk konsistensi jeli. Pada konsentrasi tinggi, jeli yang terbentuk juga menghasilkan sineresis, seperti pada kelompok IKGu 0,1 dan BaGu 0,1 . Hal ini kemungkinan karena ikatan antara air dan gelatin digantikan dengan ikatan gelatin dengan glutaraldehid. Konsistensi sampel yang ditaut silang dengan glutaraldehid dengan konsentrasi 0,025\%, seperti pada $\mathrm{BaGu} 0,025$ dan IKGu 0,025, 


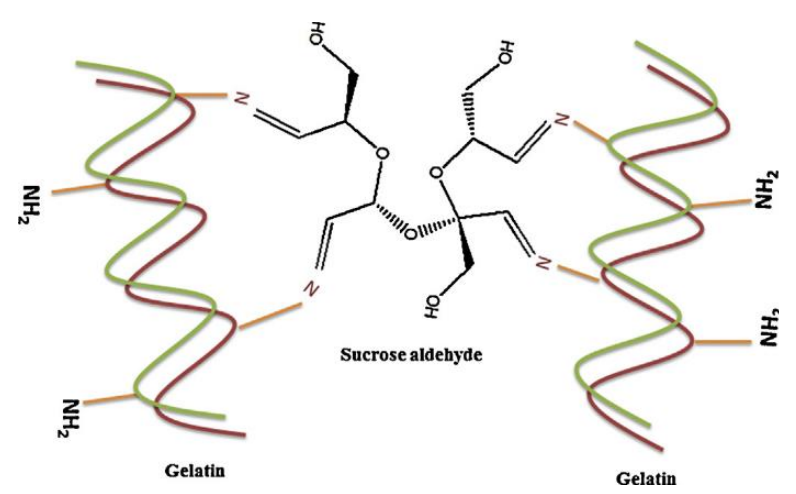

Gambar 2. Reaksi sukrosa teroksidasi dengan gelatin (Jalaja \& James, 2015)

sama dengan konsistensi sampel yang ditaut silang dengan sukrosa teroksidasi dengan konsentrasi 0,5\%, seperti pada BaSu 0,5 dan IKSu 0,5.

Konsentrasi bahan penaut silang berpengaruh terhadap indeks pengembangan. Indeks pengembangan mengambarkan kemampuan sebuah bahan dalam mengikat air. Sampel yang direndam dalam air akan 'mengembang', tetapi tidak melarut dalam pelarut. Gelatin bandeng $(37,5 \%)$ setelah ditaut silang mengalami peningkatan nilai indeks pengembangan, paling besar pada kelompok BaSu 0,1 (380\%). Demikian pula untuk sampel gelatin ikan komersil (128,6\%), paling mengembang pada kelompok IKSu 0,1 (340\%). Jika membandingkan jenis bahan penaut silang, indeks pengembangan gelatin yang ditaut silang sukrosa teroksidasi lebih besar dari pada glutaraldehid. Kemungkinan hal ini disebabkan karena glutaraldehid mengikat lebih kuat antar gelatin daripada sukrosa teroksidasi. Peningkatan konsentrasi glutaraldehid maupun sukrosa teroksidasi menurunkan indeks pengembangan. Konsentrasi yang tinggi mengakibatkan

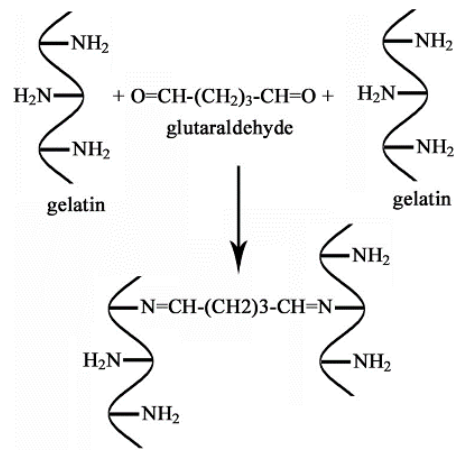

Gambar 3. Reaksi glutaraldehid dengan gelatin (Morsy, Hosny, Reisha, \& Elnimr, 2017)

pengikatan antar gelatin juga semakin besar, sehingga pengembangan gelatin menjadi lebih terbatas. Walau demikian, nilai indeks pengembangan terbesar adalah pada kontrol gelatin sapi (400), yang tidak dimodifikasi.

\section{KESIMPULAN}

Peningkatan konsentrasi bahan penaut silang dengan gelatin menyebabkan penurunan indeks pengembangan.

\section{DAFTAR PUSTAKA}

Darwin, Ridhay, A., \& Hardi, J. (2018). Kajian Ekstraksi Gelatin dari Tulang Ikan Mujair (Oreochromis mossambicus). Kovalen, Jurnal Riset Kimia, 4(1).

Jalaja, K., \& James, N. R. (2015). Electrospun gelatin nanofibers: A facile cross-linking approach using oxidized sucrose. International Journal of Biological Macromolecules, 73, 270-278. doi:10.1016/j.ijbiomac.2014.11.018

Karim, A. A., \& Bhat, R. (2009). Fish gelatin: properties, challenges, and prospects as an alternative to mammalian gelatins. Food Hydrocolloids, 23(3), 563-576. doi:10.1016/j.foodhyd.2008.07.002

Morsy, R., Hosny, M., Reisha, F., \& Elnimr, T. (2017). Developing and physicochemical evaluation of cross-linked electrospun gelatin-glycerol nanofibrous membranes for medical applications. Journal of Molecular Structure. doi:10.1016/j.molstruc.2017.01.064 
Rajalaxmi, D., Marcus, F., \& Arthur, R. (2013). Improving the mechanical and thermal properties gelatin cross-linked by cellulose nanowiskers. Carbohydrate Polymers, $\quad$ 91(2), 633-638. doi:10.1016/j.carbpol.2012.08.080

Rapika, Dzulfikar, \& Zumarni. (2016). Kualitas Fisik Gelatin Hasil Ekstraksi Kulit Sapi Dengan Lama Perendaman dan Konsentrasi Asam klorida $(\mathrm{HCl})$ yang Berbeda. Jurnal Peternakan, 13(1). doi:10.24014/jupet.v13i1.2386
Reinhard Schrieber, H. G. (2007). Gelatine Handbook: Theory and Industrial Practice. Wiley-VCH.

Santos, J. P., Esquerdo, V. M., Moura, C. M., \& Pinto, L. A. (2018). Crosslinking agents effect on gelatins from carp and tilapia skins and in their biopolymeric films. Colloids and Surfaces A: Physicochemical and Engineering Aspects, 539, 184-191. doi:0.1016/j.colsurfa.2017.12.018

Wong, S. S., \& Jameson, D. M. (2011). Chemistry of Protein and Nucleic Acid Cross-Linking and Conjugation. CRC Press. 